\title{
PENGARUH GAYA KEPEMIMPINAN TRANSFORMASIONAL DAN KOMPENSASI TERHADAP LOYALITAS KARYAWAN
}

\author{
Yosef Ang dan Edalmen \\ Program Studi Manajemen Fakultas Ekonomi dan Bisnis \\ Universitas Tarumanagara, Jakarta \\ E-mail: yosef.115189104@ stu.untar.ac.id
}

\begin{abstract}
The purpose of this study was to determine the effect of transformational leadership style and compensation on employee loyalty. The research method uses a causal method with the type of quantitative research. Data were collected from 50 respondents using saturated sampling via google form. The data is then processed using the SmartPLS version 3.0 software. The results of this study indicate that transformational leadership style has a positive and insignificant effect on employee loyalty and compensation has a positive and significant effect on employee loyalty
\end{abstract}

Keywords: Transformational Leadership Style, Compensation, Employee Loyalty

Abstrak : Tujuan penelitian ini adalah untuk mengetahui pengaruh gaya kepemimpinan transformasional dan kompensasi terhadap loyalitas karyawan. Metode penelitian menggunakan metode kausal dengan jenis penelitian kuantitatif. Data dikumpulkan dari 50 responden dengan menggunakan sampling jenuh malalui google form. Data kemudian diolah dengan menggunakan software SmartPLS versi 3.0. Hasil penelitian ini menunjukkan bahwa gaya kepemimpinan transformasional berpengaruh positif dan tidak signifikan terhadap loyalitas karyawan dan kompensasi berpengaruh positif dan signifikan terhadap loyalitas karyawan

Kata Kunci: Gaya Kepemimpinan Transformasional, Kompensasi, Loyalitas Karyawan

\section{LATAR BELAKANG}

Loyalitas merupakan keinginan seorang karyawan untuk bekerja pada suatu perusahaan dengan setia dan berada pada perusahaan dengan waktu yang sangat lama. Menurut Nitisemito (2004) loyalitas merupakan sikap setia karyawan kepada perusahaan yang akan tetap bertahan di dalam perusahaan. Wicaksono (2013) mengatakan loyalitas merupakan sikap setia pada sesuatu dengan rasa cinta, sehingga dengan rasa loyalitas yang tinggi seseorang merasa tidak perlu untuk mendapatkan imbalan dalam melakukan sesuatu untuk orang lain tempat dia meletakkan loyalitasnya. dari definisi tersebut, bila karyawan memiliki loyalitas terhadap perusahaan dan tidak begitu mengharapkan adanya kompensasi, maka bagi para pemimpin akan lebih mudah dalam melakukan strategi gaya kepemimpinan dan kompensasi untuk meningkatkan loyalitas karyawan. Loyalitas karyawan akan terus 
meningkat bila pemimpin menggunakan gaya kepemimpinan yang strategis dan kompensasi yang sesuai terhadap karyawan. Apabila loyalitas karyawannya terlalu rendah hal ini dapat menimbulkan peningkatan employee turnover rate yang dapat mempengaruhi perusahaan.

Karyawan yang tidak loyal ditandai oleh tingginya keinginan untuk keluar dari pekerjaan (turnover intention) yang akan menjadi problematika di ruang lingkup perusahaan. Turnover intention pada dasarnya adalah keinginan karyawan untuk keluar dari satu tempat kerja ke tempat kerja yang lain, namun belum sampai pada tahap realisasi yaitu perpindahan kerja dari satu tempat ke tempat lainnya. Intensi keluar (turnover intention) diartikan sebagai kadar atau tingkat niat tenaga kerja keluar dari perusahaan, turnover mengarah pada kenyataan akhir yang dihadapi perusahaan berupa jumlah karyawan yang meninggalkan perusahaaan pada, periode tertentu. Faktor factor yang mempengaruhi turnover intention dari perusahaan terhadap karyawan diantaranya adalah kepemimpinan, kepuasan kerja dan komitmen organisasional (Sobirin, dkk 2016). Kepemimpinan merupakan sifat penting pimpinan dalam pengorganisasian sumber daya manusia yang baik. Pimpinan dan kepemimpinan yang diembannya memiliki fungsi strategis yang menentukan kinerja sumber daya manusia. Pemimpin yang melaksanakan kepemimpinannya secara efektif, dapat menggerakan orang/personil ke arah tujuan yang dicita-citakan, akan menjadi panutan dan teladan. Sebaliknya pemimpin yang keberadaannya hanya sebagai figur dan tidak memiliki pengaruh serta kemampuan kepemimpinan, akan mengakibatkan kinerja sumber daya manusia menjadi lambat, karena tidak memiliki kapabilitas dan kecakapan untuk menghasilkan kinerja yang baik.

Gaya kepemimpinan seseorang pemimpin pada sebuah perusahaan serta pemberian kompensasi yang tidak cukup sering terjadi dalam suatu perusahaan sehingga akan menyebabkan menurutnya tingkat kepuasan karyawan dan pada akhirnya akan dapat menurunkan loyalitas karyawan dalam perusahaan. Oleh karena itu perlu peran gaya kepemimpinan yang kuat serta kompensasi yang tepat untuk meningkatkan loyalitas karyawan. Loyalitas karyawan dapat tercermin dari besaran angka perputaran karyawan (turnover). Menurut Rivai (2004), kepemimpinan merupakan suatu proses pemimpin yang dapat memengaruhi atau memberi contoh kepada bawahannya melalui proses komunikasi dalam upaya mencapai tujuan organisasi. Dalam sebuah kepemimpinan terdapat gaya kepemimpinan yang diharapkan dapat untuk memajukan perusahaan. Setiap pemimpin pasti memiliki cara memimpin yang berbeda yang disebut gaya kepemimpinan, gaya kepemimpinan yang baik dilakukan untuk meningkatkan loyalitas karyawan. (Turnover intention) yang tinggi menunjukkan bahwa loyalitas karyawan cenderung mengalami penurunan. Penelitian yang dilakukan oleh Santi \& Kurniati (2020), menemukan bahwa kepemimpinan memiliki pengaruh positif dan signifikan terhadap turnover intention. Hal ini menujukkan bahwa salah satu faktor yang berpengaruh terhadap loyalitas karyawan adalah gaya kepemimpinan. Loyalitas akan bisa meningkat apabila pemimpin bisa memotivasi dan mengarahkan bawahannya ke arah yang benar untuk menyelesaikan suatu masalah dalam pekerjaan guna untuk mencapai tujuan. Penelitian yang dilakukan oleh Kadek Suhendra Wina Dwipayoga (2013) Sieny Carolina Wellyanto dan Grace Angelica Halim. (2017) Lola Melino Citra dan Muhammad Fahmi. (2019) Ni Putu Eka Fajariani dan I.B. Ketut Surya. (2015) menemukan bahwa gaya kepemimpinan berpengaruh positif terhadap loyalitas karyawan yang dapat diartikan bahwa pemimpin yang kuat dan bisa dipercaya oleh karyawan 
akan dihormati dan menjadi panutan karyawan sehingga karyawan bisa meningkat loyalitasnya terhadap perusahaan. Karyawan juga merasa mereka terbawa ke arah yang benar oleh pemimpin dan karyawan melakukan pekerjaan dengan semangat untuk mencapai tujuan yang telah ditetapkan oleh perusahaan.

Kompensasi juga dapat menjadi variabel yang berpengaruh dalam upaya meningkatkan loyalitas karyawan di dalam perusahaan. Pemimpin harus mengerti lebih dalam terhadap karyawan dan mencari tahu apa yang mereka inginkan untuk meningkatkan loyalitas mereka terhadap perusahaan, dengan memberikan kompensasi yang tepat untuk karyawan, maka karyawan akan bekerja lebih semangat dan bekerja secara maksimal. Hasibuan (2011) mengemukakan bahwa kompensasi merupakan pendapatan yang berbentuk barang langsung dan tidak langsung yang memberikan kepada karyawan sebagai imbalan yang mereka berikan kepada perusahaan. Kepuasan kompensasi akan mempengaruhi perilaku karyawan untuk bekerja lebih semangat dan loyalitas karyawan (Handoko, 2008). Hasil penelitian Agustina Heryati (2016) membuktikan bahwa kompensasi berpengaruh positif terhadap loyalitas karyawan. Dengan ada pemberian kompensasi yang cukup kepada karyawan akan membuat karyawan tersebut tidak ingin keluar dari perusahaan sehingga loyalitas karyawan kepada pe rusahaan semakin meningkat pula. Menurut Mathis \& Jackson (2006:419) kompensasi merupakan faktor penting yang mempengaruhi bagaimana dan mengapa orang-orang memilih bekerja di suatu perusahaan. Hasil penelitian yang dilakukan oleh Vera Violetta \& Edalmen (2020) menunjukkan bahwa kompensasi mempunyai pengaruh positif secara langsung terhadap retensi karyawan. Kompensasi juga berpengaruh melalui variabel mediasi kepuasan kerja terhadap retensi karyawan. Hal ini menunjukkan bahwa keinginan karyawan untuk bertahan lebih lama dan tidak ingin berpindah ke perusahaan lain dipengaruhi oleh kompensasi yang mereka dapatkan. Karyawan seperti inilah yang biasanya memiliki loyalitas tinggi terhadap perusahaan dan dapat meningkatkan kinerja perusahaan.. Hasil pene;itian yang dilakukan olehn Agustina Heryati (2016). Kadek Suhendra Wina Dwipayoga dan I. G. A Dwi Adnyani (2013). menemukan bahawa kompesasi mempunyai pengaruh positif signifikan terjadap loiyalitas karyawan. Apabila kompensasi yang diperoleh karyawan tidak layak dan adil maka niat karyawan untuk bertahan dalam jangka lama akan menurun. Pemberian kompensasi yang baik dan adil juga dapat meningkatkan kepuasan kerja. Jika karyawan memiliki ketidakpuasan kerja yang tinggi maka tidak akan bertahan untuk tinggal dan bekerja di perusahaan tersebut dalam jangka waktu yang lama. Atau sebaliknya jika tingkat kepuasan kerja meningkat maka akan diikuti dengan meningkatnya retensi karyawan. Penelitian Neog (2015) menyatakan bahwa penghargaan memiliki hubungan positif dengan retensi karyawan, tetapi hubungannya tidak signifikan. Hasil yang berbeda juga dilaporkan oleh Filian Mufcha Ihwana, Isharijadi dan Anggita Langgeng Wijaya (2017) yang menyatakan bahwa bahwa kompensasi tidak berpengaruh terhadap loyalitas karyawan.

Berdasarkan latar belakang diatas dimana masih terdapat perbedaan hasil penelitian sebelumnya tentang pengaruh kepemimpinan tranformasional dan kompensasi terhadap loyalitas karyawan maka peneliti melakukan penelitian ini yang diharapkan akan dapat memperkaya literatur hasil temuan dan kepustakaan tentang variabel variabel yang berpengaruh terhadap loyalitas karyawan. 


\section{KAJIAN TEORI}

Referensi yang menjelaskan tentang kepemimpinan transformasional diantaranya dikemukakan oleh Robbins \& Judge (2015:377), "Transformasional leaders is leaders who inspire followers to transcend their own self-interests and who are capable of having a profound and extraordinary effect on followers". Artinya pemimpin transformasional adalah pemimpin yang dapat menginspirasi karyawannya untuk melampaui kepentin Menurut Yukl (2005), kepemimpinan transformasional mencakup tiga komponen utama yaitu kharisma, stimulasi intelektual dan perhatian yang berorientasi individu. Kepemimpinan transformasional dicirikan dengan suatu kondisi dimana para pemimpin memotivasi para pengikutnya melalui cara di bawah sebagai berikut : a). membuat mereka sadar akan pentingnya hasil-hasil suatu pekerjaan, b)mendorong mereka untuk lebih mementingkan organisasi atau kelompok tim diatas kepentingan pribadi dan c) mengaktifkan kebutuhankebutuhan mereka pada tingkatan yang lebih tinggigan mereka sendiri dan mampu memberikan pengaruh yang besar kepada para karyawannya. Sedangkan menurut MacKenzie Podsakoff, \& Paine (1999), kepemimpinan transformasional adalah meningkatkan partisipasi dan pemberdayaan bawahan dalam aktivitas organisasi, dimana kepemimpinan transformasional berupaya untuk melakukan perubahan ke arah yang lebih baik. Dalam model kepemimpinan ini diyakini akan mengarah pada kinerja superior dalam organisasi yang sedang menghad,api perubahan. Berikut adalah sepuluh indikator yang digunakan untuk mengukur variabel kepemimpinan tranformasional pada penelitian ini (Indra Kharis 2015), a)dapat dibanggakan, b).dapat dipercaya c).dapat dihormati, d).mempunyai loyalitas, e).pemimpin mengkomunikasikan dengan harapan yang tinggi, f). menggunakan jabatan dalam memimpin, g).pemimpin mendorong bawahan lebih kreatif, h).menghilangkan keangganan bawahan untuk mengeluarkan ide, i).perhatian terhadap karyawan dan j).pemberian penghargaan kepada karyawan yang berprestasi

Menurut Simamora (2006) kompensasi merupakan suatu bayaran yang diberikan perusahaan untuk dapat meningkatkan produktivitas karyawan untuk mencapai keunggulan kompetitif yang telah ditetapkan perusahaan. dari definisi diatas dapat diartikan kompensasi merupakan suatu bayaran atau imbalan yang dikeluarkan oleh perusahaan sebagai imbalan kepada karyawan terhadap pekerjaan yang telah mereka kepada perusahaan. dengan pemberian kompensasi yang cukup dan adil kepada karyawan maka kreativitas dan loyalitas akan meningkat. Dengan pemberian kompensasi terjalinlah ikatan kerjasama formal antara majikan dengan karyawan. Karyawan harus mengerjakan tugasnya dengan baik, sedangkan pengusaha/majikan harus membayar kompensasi. Menurut Steers \& Porter (1983:520), loyalitas akan tercipta, bila karyawan sudah merasa kebutuhan hidup sudah tercukupi dari pekerjaan, maka loyalitas akan tercipta. Menurut Agustina Heryati (2016) indikator yang dapat digunkana unutk menilai kompensasi adalah a) gaji dan kebutuhan karyawan, b).gaji dan jabatan kerja karyawan, c).kemampuan kerja karyawan, d).motivasi kerja karyawan, e).bonus dan insentif terhadap semangat kerja karyawan, f).asuransi kesehatan, g).uang pesangon, h). tunjangan cuti dan i).tunjangan hari raya

Loyalitas merupakan kesadaran diri karyawan yang ditunjukkan dengan kesetiaanya terhadap suatu perusahaan walau perusahaan dalam keadaan baik dan buruk (Hermawan dan Riana, 2013). Loyalitas juga ditunjukkan oleh tingkat retensi karyawan dan tingkat turnover karyawan. Karyawan dengan loyalitas tinggi tingkat retensinya juga tinggi dan tingkat turnover cenderung lebih kecil. Dari uraian diatas tersebut dapat diartikan 
bahwa loyalitas merupakan kesadaran diri karyawan yang menunjukkan rasa kesetiaan kepada perusahaan. Untuk mengukur variabel loyalitas karyawan digunakan indikator yang diadopsi dari Trianasari (2005) sebagai berikut : a) taat pada peraturan yang sudah ditetapkan, b).tanggung jawab kepada perusahaan untuk menyelesaikan tugas yang telah dibagikan, c).kemauan untuk bekerja diperusahaan, d).rasa memiliki terhadap perusahaan, e).hubungan antar pribadi dengan orang lain, f).kesukaan terhadap pekerjaan yang sudah dibagikan dan g).kesetiaan dan pengabdian kepada perusahaan

Kepemimpinan transformasional yang dipraktekkan oleh pemimpin perusahaan akan dapat menimbulkan rasa kepuasan dalam diri karyawan dan pada akhirnya akan meningkatkan loyalitas karyawan. Demikian juga halnya dengan kompensasi, kompensasi yang cukup akan mempengaruhi loyalitas karyawan. Penelitian ini menjelaskan pengaruh gaya kepemimpinan transformasional dan kompensasi terhadap loyalitas karyawan pada PT.Hipernet Indodata di Jakarta dengan model penelitian yang dapat digambarkan sebagai berikut:

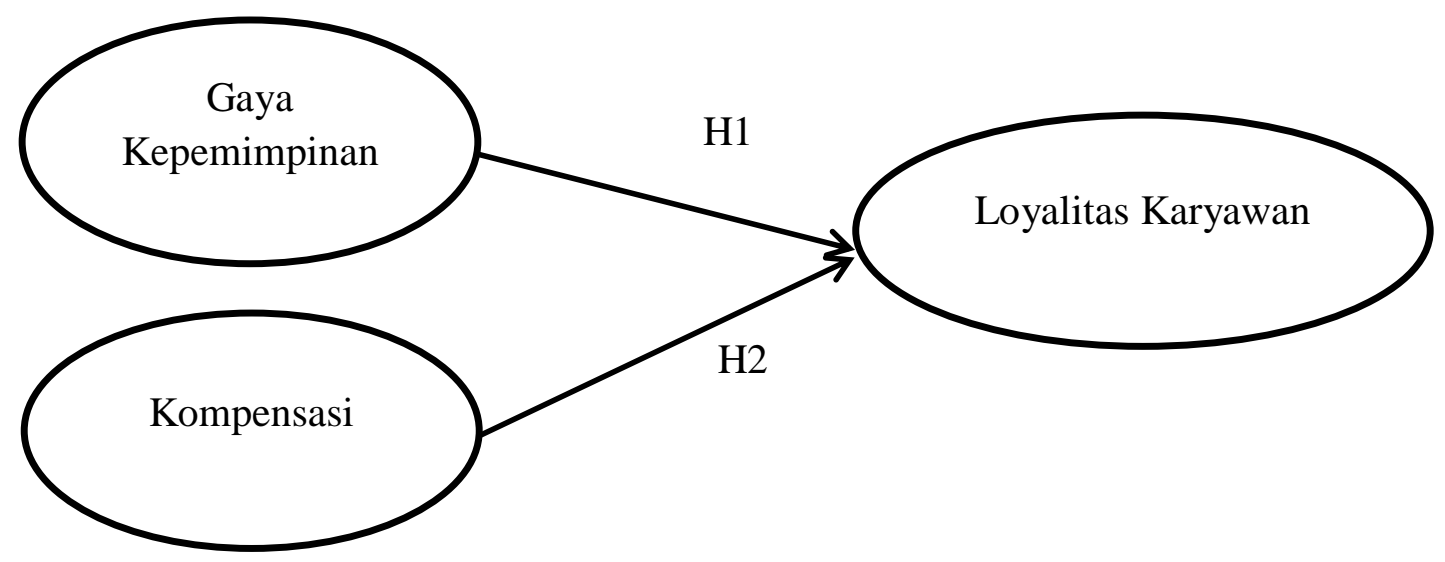

Gambar 1

\section{Model Penelitian}

Berdasarkan model penelitian diatas, hipotesis dapat dirumuskan sebagai berikut:

H1 : Gaya kepemimpinan transformasional mempunyai pengaruh terhadap loyalitas karyawan

H2 : Kompensasi mempunyai pengaruh terhadap loyalitas karyawan

\section{METODOLOGI}

Data diambil dari karyawan PT. Hipernet Indodata di Jakarta yang berjumlah 50 orang dengan sampling jenuh dengan menggunakan. instrumen kuisioner online menggunakan google form. Metode penelitian yang digunakan adalah adalah teknik konklusif kausal.. Data diolah menggunakan metode Partial Least Square (PLS) dengan aplikasi Smart-PLS versi 3. Pengolahan dilakukan pada outer model untuk menguji validitas dan reliabilitas. Uji validitas 
dilihat dari nilai faktor loading convergent validity pada variabel laten dengan indikatorindikatornya yang diharapkan > 0.5 (Abdillah \& Hartono, 2015). Selanjutnya, Uji reliabilitas digunakan untuk menguji nilai reliabilitas dari setiap blok indikator yang mengukur sebuah konstruk, dimana konstruk dinyatakan reliabel (hasil pengukuran yang relatif sama dalam waktu yang berbeda) jika nilai cronbach's alpha > 0.7 (Eisingerich dan Rubera, 2010). pengolahan dilakukan pada inner model untuk menguji hipotesis yang telah dihasilkan. Sebelum pengujian hipotesis, pertama dilakukan pengujian besarnya pengaruh variabel independen terhadap variabel dependen dengan melihat nilai $R$-square $\left(R^{2}\right)$. Pengujian hipotesis bertujuan, untuk melihat pengaruh yang terjadi lihat (positif/ negatif) dari coefficient yang dihasilkan, dan menggunakan t-statistics $>1,96$ (hipotesis tidak ditolak) dan p-values < 0,05 (hipotesis signifikan) (Hartono 2008)

\section{HASIL ANALISIS DATA}

Analisis data dilakukan melalui uji outer model dan inner model. Berikut gambar hasil pengujian outer model yang menggunakan analisis PLS Algoritm:

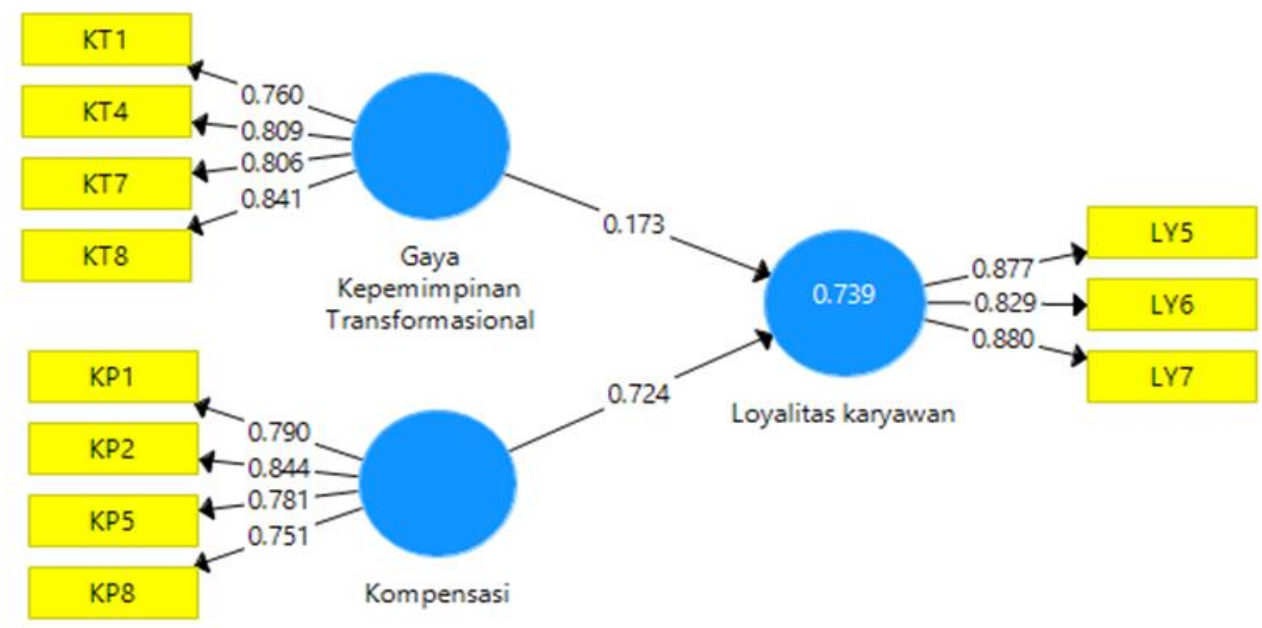

\section{Gambar 2}

\section{Hasil PLS Algorithm}

Hasil dari pengujian outer model terdapat angka loading factor yang harus dieliminasi karena tidak memenuhi syarat > 0,5 . Adapun indikator yang dieliminasi adalah KT2, KT3, KT5, KT6, KT9, KT10, KP3, KP4, KP6, KP7, KP9, LY1, LY2, LY3. Pada gambar 2 diatas semua indiaktor yang digunakan sudah memenuhi syarat karena nilai loading factornya $>0,5$. Perhitungan AVE disajikan pada table 1 berikut : 
Tabel 1

Tabel AVE

\begin{tabular}{|l|c|}
\hline \multicolumn{1}{|c|}{ Variabel } & AVE \\
\hline Gaya Kepemimpinan Transformasional & 0.647 \\
\hline Kompensasi & 0.628 \\
\hline Loyalitas Karyawan & 0.744 \\
\hline
\end{tabular}

Sumber : Data diolah dengan Smart PLS 3

Variabel gaya kepemimpinan transformasional memiliki nilai AVE sebesar 0.647 dan variabel kompensasi memiliki nilai AVE sebesar 0.628 sedangkan pada variabel loyalitas karyawan memiliki nilai sebesar 0.744. Berdasarkan hasil uji validitas konvergen diatas, maka dapat disimpulkan uji ini lolos karena nilai AVE telah melampaui angka 0.50. Hasil uji validitas diskriminan terlihat pada table 2 berikut :

Tabel 2

Hasil Uji Validitas Diskriminan (Cross Loading)

\begin{tabular}{|c|c|c|c|}
\hline Indikator & $\begin{array}{c}\text { Gaya } \\
\text { Kepemimpinan } \\
\text { Transformasional }\end{array}$ & Kompensasi & $\begin{array}{c}\text { Loyalitas } \\
\text { Karyawan }\end{array}$ \\
\hline KT1 & $\mathbf{0 . 7 6 0}$ & 0.563 & 0.455 \\
\hline KT4 & $\mathbf{0 . 8 0 9}$ & 0.448 & 0.481 \\
\hline KT7 & $\mathbf{0 . 8 0 6}$ & 0.623 & 0.609 \\
\hline KT8 & $\mathbf{0 . 8 4 1}$ & 0.701 & 0.680 \\
\hline KP1 & 0.646 & $\mathbf{0 . 7 9 0}$ & 0.720 \\
\hline KP2 & 0.539 & $\mathbf{0 . 8 4 4}$ & 0.730 \\
\hline KP5 & 0.545 & $\mathbf{0 . 7 8 1}$ & 0.644 \\
\hline KP8 & 0.617 & $\mathbf{0 . 7 5 1}$ & 0.591 \\
\hline LY5 & 0.635 & 0.796 & $\mathbf{0 . 8 7 7}$ \\
\hline LY6 & 0.550 & 0.633 & $\mathbf{0 . 8 2 9}$ \\
\hline LY7 & 0.639 & 0.760 & $\mathbf{0 . 8 8 0}$ \\
\hline
\end{tabular}

Sumber Data diatas diolah dengan SmartPLS 3

Berdasarkan tabel diatas, diketahui nilai dari setiap indikator variabel konstruk dalam mengukur variabel konstruk yang lain. Uji validitas ini dikataan valid bila cross loading pada konstruk memiliki nilai yang tinggi dibandingkan dengan nilai faktor loading pada konstruk yang lain. Dari table diatas dapat disimpulkan bahwa cross loading konstruk memiliki nilai yang lebih tinggi dibandingkan nilai konstruk pada variabel yang lain. Untuk perhitungan Cronbach Alpha disajikan pada table 3 berikut :

Tabel 3

Hasil Analisis Reabilitas

\begin{tabular}{|c|c|}
\hline Variabel & Croncbach Aplha $>0.7$ \\
\hline Gaya Kepemimpinan Transformasional & 0.821 \\
\hline Kompensasi & 0.802 \\
\hline
\end{tabular}




\begin{tabular}{|c|c|}
\hline Loyalitas Karyawan & 0.828 \\
\hline
\end{tabular}

Sumber Data diatas diolah dengan SmartPLS 3

Pada tabel diatas, dapat dilihat nilai Cronbach Alpha dari setiap variabel telah melewati nilai kritis yaitu lebih besar dari 0.7. maka dapat disimpulkan setiap varibael dapat dikatakan reliabel. Berikut adalah hasil $\mathrm{Uji}^{2}$

Tabel 4

Hasil R Square

\begin{tabular}{|c|c|}
\hline Variabel Dependen & R-Square \\
\hline Loyalitas & 0.739 \\
\hline
\end{tabular}

Sumber Data diatas diolah dengan SmartPLS 3

Berdasarkan tabel diatas, dapat dilihat nilai R-Square sebesar 0.739 atau $73.9 \%$ yang menunjukkah bahwa perubahan pada variabel loyalitas karyawan dapat dijelaskan oleh variable gaya kepemimpinan transformasional dan kompensasi sebesar 73,9 \%, sedangkan sisanya sebesar $26,1 \%$ dijelaskan oleh variabel variabel lainnya penelitian ini. Nilai RSquare sebesar 0,739 ini dikategorikan sedang.

Berikut adalah hasil uji path koefisien :

Tabel 5

Hasil Uji Path Coefficient

\begin{tabular}{|l|c|c|c|c|c|}
\hline & $\begin{array}{c}\text { Original } \\
\text { Sampel } \\
(\mathrm{O})\end{array}$ & $\begin{array}{c}\text { Sampel } \\
\text { Mean } \\
(\mathrm{M})\end{array}$ & $\begin{array}{c}\text { Standard } \\
\text { Deviation } \\
(\mathrm{STDEV})\end{array}$ & $\begin{array}{c}\text { T-Statistic } \\
(|\mathrm{O} / \mathrm{STDEV}|)\end{array}$ & $\begin{array}{c}\text { P } \\
\text { Values }\end{array}$ \\
\hline $\begin{array}{l}\text { Gaya Kepemimpinan } \\
\text { Transformasional -> Loyalitas } \\
\text { karyawan }\end{array}$ & 0.173 & 0.183 & 0.103 & 1.635 & 0.094 \\
\hline $\begin{array}{l}\text { Kompensasi -> Loyalitas } \\
\text { karyawan }\end{array}$ & 0.724 & 0.725 & 0.104 & 7.013 & 0.000 \\
\hline
\end{tabular}

Sumber Data diatas diolah dengan SmartPLS 3

Berdasarkan tabel diatas, maka dapat disimpulkan Gaya kepemimpinan transformasional berpengaruh terhadap Loyalitas karyawan bernilai positif sebesar 0.173 dan Kompensasi berpengaruh terhadap Loyalitas karyawan bernilai positif sebesar 0.724, maka dapat disimpulkan bahwa kompensasi mempunyai pengaruh lebih besar terhadap loyalitas karyawan dibandingkan gaya kepemimpinan transformasional. Uji Hipotesis dilakukan dengan meode bootstrapping seperti terlihat pada gambar 3 berikut ini 


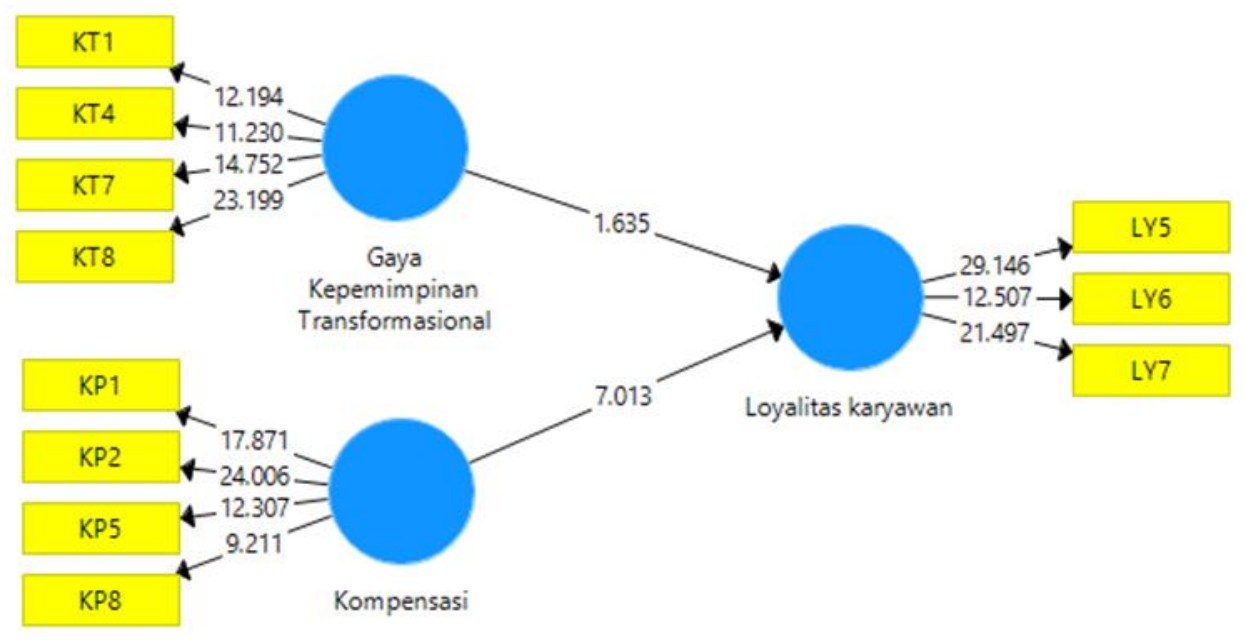

Gambar 3

Hasil Uji Bootstrapping Path Coefficient

Berikut adalah hasil uji hipotesis :

1. Uji pengaruh gaya kepemimpinan transformasional terhadap loyalitas karyawan H1: Terdapat pengaruh positif gaya kepemimpinan transformasional terhadap loyalitas karyawan dengan path coefficient 0.173 . Berdasarkan tabel diatas variabel gaya kepemimpinan transformasional terhadap loyalitas karyawan memiliki nilai tstatistic sebesar $1.635<1.96$ dan nilai p-value sebesar 0.094 maka dapat disimpulkan bahwa variabel gaya kepemimpinan mempunyai pengaruh positif positif terhadap loyalitas karyawan akan tetapi tidak signifikan secara statistik

2. Uji pengaruh kompensasi terhadap loyalitas karyawan

$\mathrm{H} 2$ : Terdapat pengaruh positif kompensasi terhadap loyalitas karyawan dengan path coefficient 0.724. Berdasarkan tabel diatas variabel kompensasi terhadap loyalitas karyawan memiliki nilai t-statistic sebesar $7.013>1.96$ dan nilai p-value sebesar 0.000 maka dapat disimpulkan bahwa terdapat pengaruh positif dan signifikan variabel kompensasi terhadap loyalitas karyawan .

\section{DISKUSI}

Penelitian ini menemukan bahwa gaya kepemimpinan transformasional memiliki pengaruh positif terhadap loyalitas karyawan, akan tetapi pengaruh tersebut tidaklah signifikan secara statistik. Hal ini menunjukkah bahwa gaya kepemimpinan transformasional yang dipraktekkan oleh pimpinan perusahaan belum dapat meningkatkan loyalitas karyawan PT Hipernet Indodata. Hasil penelitian ini berbeda dengan penelitian yang dilakukan Citra, L. M. \& Fahmi, M. (2019), Sieny Carolina Wellyanto dan Grace Angelica Halim (2017) yang 
menyatakan bahwa gaya kepemimpinan transformasional berpengaruh positif dan signifikan terhadap loyalitas karyawan. Hasil ini juga berbeda dengan penelitian yang dilakukan oleh Santi Gunawan \& Kurniati W. Andani (2020) yang menyatakan bahwa gaya kepemimpinan mempunyai pengaruh positif dan signifikan terhadap turnover intention. Kepemimpinan transformasional dicirikan sebagai pemimpin yang berfokus pada pencapaian perubahan nilai-nilai, kepercayaan, sikap, perilaku, emosional, dan kebutuhan bawahan menuju perubahan yang lebih baik di waktu yang mendatang. Gaya kepemmpinan seperti ini diharapkan dapat meningkatkan loyalitas karyawan, sehingga tingkat turnover karyawan dapat diminimalkan Indikator yang paling besar pengaruhnya terhadap variabel gaya kepemimpinan transformasional dalam penelitian ini adalah pemimpin yang mempunyai loyalitas dan indikator yang kecil perannya adalah kepemimpinan yang dapat dibanggakan.

Penelitian ini menemukan bahwa kompensasi berpengaruh positif dan signifikan terhadap loyalitas karyawan. Kompensasi yang semakin baik akan meningkatkan loyalitas karyawan terhadap perusahaan Dengan pemberian kompensasi yang baik dan adil kepada karyawan dapat meningkatkan loyalitas karyawan dan rasa setia dan bahkan bisa meningkatkan motivasi kerja karyawan. Hasil penelitian ini memperkuat penelitian yang dilakukan Vera vio \& Edalmen (2020) yang menemukan bahwa secara langsung mupun tidak langsung kompensasi mempengaruhi retensi karyawan. Hasil penelitian ini juga sejalan dengan penelitian yang dilakukan Agustina Heryati (2016), Kadek Suhendra Wina Dwipayoga dan I. G. A Dwi Adnyani (2013) yang menyatakan bahwa kompensasi mepunyai pengaruh positif dan signifikan terhadap loyalitas karyawan. Penelitian berbeda dengan yang dilakukan oleh Filian Mufcha Ihwana, Isharijadi dan Anggita Langgeng Wijaya (2017) menunjukkan bahwa kompensasi tidak berpengaruh terhadap loyalitas karyawan. Indikator yang paling berperan dalam menentukan variabel kompensasi adalah kesempatan untuk memberikan promosi jabatan dan yang paling kecil pengaruhnya adalah pembayaran uang lembur.

\section{PENUTUP}

Berdasarkan hasil penelitian ini, maka ada beberapa saran yang dapat diberikan oleh kepada PT Hipernet Indodata

1) Gaya kepemiminan berpengaruh terhadap loyalitas karyawan, dimana pemimpin sudah mampu untuk meningkatkan loyalitas tersebut dengan baik akan tetapi pimpinan belum mampu menjadi panutan yang dapat dibanggakan oleh karyawan, sehingga perlu ditingkatkan lagi dimaka yang akan datang.

2) Perusahaan sudah dapat memberikan kompensasi yang baik kepada karyawan termasuk pemberian kesempatan untuk promosi jabatan bagi karyawan yang berprestasi akan tetapi perusahaan juga harus memperhatikan kompensasi lainnya berupa uang lembur yang sesuai agar loyalitas karyawan semakin meningkat lagi dimasa yang akan datang. 
3) Loyalitas karyawan terhadap perusahaan sudah baik, akan tetapi karyawan sesungguhnya kurang menyukai pekerjaan yang mereka lakukan, sehingga loyalitas yang ditunjukkan itu sebenarnya mudah sekali berubah, dan harus menjadi perhatian perusahaan ke depannya.

Penelitian selanjutnya diharapkan bisa menambah variabel lain yang belum dimasukkan dalam penelitian ini seperti, lingkungan kerja, kepuasan kerja, dan variabel lainnya untuk perusahaan yang berbeda yang akan dapat memberikan hasil yang berbeda. dan dapat memperkaya literatur dan keputakaan tentang loyalitas karyawan ini.

\section{DAFTAR PUSTAKA}

Abdillah, W. \& Hartono (2015). Partial Least Square (PLS) Alternatif Structural Equation Modeling (SEM) dalam Penelitian bisnis. Yogyakarta: CV Andi Offset.

Citra, L. M. \& Fahmi, M. (2019). Pengaruh Kepemimpinan Kepuasan Kerja dan Motivasi Kerja terhadap Loyalitas Karyawan. Maneggio: Jurnal Ilmiah Magister Manajemen, Vol.2, No.2, ISSN 2623-2634, 214-225.

Dwipayoga, W. K. S., \& Adnyani, D. (2013). Pengaruh Lingkungan Kerja Fisik, Kepemimpinan dan Kompensasi terhadap Loyalitas Karyawan pada PT. Gino Valentino Bali. E-Jurnal Manajemen Vol. 2, No.2, ISSN 2301-8912, 137-152.

Eisingerich, A. B., \& Rubera, G. (2010). Drivers of Brand Commitment: A CrossNational Investigation. Journal of International Marketing, 18(2), 64-79. http://doi.org/10.1509/jimk.18.2.64.

Fajariani,N. P. E \& Surya, I. B. K. (2015). Pengaruh Pengalaman Kerja dan Kepemimpinan Transoformasional terhadap Loyalitas Karyawan. E-Jurnal Manajemen Unud, Vol. 4, No.4, ISSN: 2302-8912, 930-942.

Hasibuan, Malayu. 2011. Manajemen Sumber dan Daya Manusia Edisi Revisi. Jakarta: Bumi Aksara.

Handoko, T.H. (2008). Manajemen Personalia dan Sumber Daya Manusia. Yogyakarta: Liberty.

Hartono, Jogiyanto. 2008. Teori Portofolio dan Analisis Investasi. Edisi Kelima. BPFE. Yogyakarta

Heryati, A. (2016). Pengaruh Kompensasi dan Beban Kerja Terhadap Loyalitas Karyawan Di Departemen Operasi PT. Pupuk Sriwidjaja Palembang. Jurnal Ecoment Global, Vol.1, No.2, ISSN 2540-816X, 56-75.

Hermawan, I Ketut Andy dan I Gede Riana. 2013. Analisis Faktor-Faktor yang Menentukan Loyalitas Karyawan pada PT. Inti Buana Permai Denpasar Bali. 2,h: 624-642.

Ihwana, F. M, Isharijadi, \& Wijaya, A. L. (2017). Pengaruh Kompensasi dan Motivasi Kerja terhadap Loyalitas perawat. Ilmiah Pendidikan Akuntansi Vol.5, No.1, 294-306.

Kharis, I. (2015). Pengaruh Gaya Kepemimpinan Transformasional Terhadap Kinerja Karyawan dengan Motivasi Kerja sebagai Variabel Intervening (Studi pada Karyawan Bank Jatim Cabang Malang).

Mathis, Robert L dan Jackson, John H. 2006. Manajemen Sumber Daya Manusia, Edisi 10. Jakarta : Salemba Empat.

MacKenzie, S.B., Podsakoff, P.M., and Paine, J.B. (1999). Do Citizenship Behaviors Matter More for Managers Than of Salespeople, Journal of the Academy of Marketing Science, $27(4) ; 390-410$. 
Nitisemito, A.S. 2004, Manajemen Personalia (Manajemen Sumber Daya Manusia). Jakarta : Ghalia Indonesia.

Neog, B. B., \& Barua, M. (2015). Factors Affecting Employee's Retention in Automobile

Rivai, Veithzal. 2004. "Manajemen Sumber Daya Manusia Untuk Perusahaan, Cetakan Pertama, Jakarta, PT. Raja Grafindo Persada.'

Robbins, S., \& Judge, T. (2015). Organizational Behavior (16th edition). England: Pearson Education Inc.

Santi Gunawan \& Kurniati W.Andani (2020). Faktor-Faktor yang mempengaruhi Turnover Intention Karyawan pada PT Permata Prima Canindodi Jakarta. Jurnal Manajerial dan Kewirausahaan, Volume II No.3/2020 Hal: 793-8028k

Shobirin, Muhamad, Maria M. Minarsih, dan Azis Fathoni (2016) Analisis Pengaruh Kepemimpinan, Komitmen Organisasi Dan Kepuasan Kerja Terhadap Keinginan Pindah Kerja Karyawan PT. Bank BTPN Mitra Usaha Rakyat Area Semarang. Journal of Management. Vol.02 No.02, Hal. 1-18.

Steers, R., \& Porter, L. (1983). Motivational and Work Behavior. New York: Mc Graw Hill Book Company.

Simamora, H. (2006). Manajemen Sumber Daya Manusia. Edisi 3. Cetakan Kedua. Yogyakarta : STIE YKPN.

Trianasari, Y. (2005). Hubungan Antara Persepsi Terhadap Insentif dan Lingkungan Kerja dengan Loyalitas Kerja. Surakarta: Fakultas Psikologi Universitas Muhammadiyah Surakarta.

Vera Violetta, Edalmen (2020). Pengaruh Kompensasi terhadap Retensi Karyawan dengan Kepuasan Kerja sebagai Variabel Mediasi. Jurnal Manajerial dan Kewirausahaan, Volume II No.4/2020 Hal:1086-1095.

Wicaksono, P. E. (2013). Analisis Pertumbuhan Ekonomi dan Faktor Faktor yang Mempengaruhi. Jurnal.

Wellyanto, S. C., \& Halim, G. A. (2017). Analisis Pengaruh Gaya Kepemimpinan terhadap Loyalitas Karyawan. Jurnal Hospitality dan Manajemen Jasa, 328-341.

Yukl, G. (2005). Kepemimpinan Dalam Organisasi Edisi 5. Jakarta: Indeks. 